Bradley, Travis G. and Ann Marie Delforge. In press. Historical Romance Linguistics: Retrospectives and Perspectives, ed. by Deborah Arteaga and Randall Gess. Amsterdam: John Benjamins.

\title{
SYSTEMIC CONTRAST AND THE DIACHRONY OF SPANISH SIBILANT VOICING
}

\author{
TRAVIS G. BRADLEY AND ANN MARIE DELFORGE \\ University of California, Davis
}

\section{Introduction}

According to the Saussurian view, a phonological form must be understood in the context of the larger system of forms of which it is a part. The notion of systemic contrast plays a key role in structuralist accounts of sound change, especially in the work of Martinet $(1952,1955,1964)$. More recently, Dispersion Theory (DT; Flemming 1995, 2002) integrates the functionalist principles of Adaptive Dispersion Theory (Lindblom 1986, 1990) into Optimality Theory (OT; Prince \& Smolensky 1993) and has been subsequently developed in different directions by Ní Chiosáin \& Padgett (2001), Padgett (2003a,b,c), and Sanders $(2002,2003)$. DT has been widely applied to vowel patterning, but less so to consonants. Researchers applying DT to historical sound change have attempted to make Martinet's structuralist ideas more explicit by appealing to constraints that require surface contrasts to be maintained and kept perceptually distinct (Baker 2003, Holt 2003, Itô \& Mester, in press, Padgett 2003b, Padgett \& Zygis 2003, Sanders 2002, 2003). The present study contributes to this line of research by analyzing the loss of sibilant voicing contrasts in medieval Spanish, as well as the reemergence of sibilant voicing in several modern dialects.

Intervocalic sibilant voicing contrasts developed in the variety of Late Latin spoken on the Iberian Peninsula as a result of assimilatory and weakening processes occurring in dialects throughout the Western Romance area. While the other major modern Romance languages preserved the segments produced by these innovations, distinctively voiced sibilants began to merge with their voiceless counterparts in Old Castile during the early Middle Ages. Devoicing spread southward over a period of several hundred years, finally eliminating voiced sibilants from the speech of all areas under Castilian control by the 1580s. Descriptions of conservative varieties of modern Spanish generally indicate that $/ \mathrm{s} /$, the sole sibilant survivor of early modern changes in place of articulation, exhibits phonetically gradient and variable voicing in syllablefinal position preceding a voiced consonant. Nevertheless, several studies of 
American and Peninsular Spanish dialects have documented voiced productions of prevocalic and prepausal sibilants. In highland Ecuadorian Spanish, voicing signals the word-final status of /s/, thereby allowing a surface distinction between phrases such as $h a[\mathrm{z}]$ ido "you have gone" versus ha [s]ido "s/he, it has been" (cf. modern Castilian Spanish, in which both are pronounced with a voiceless sibilant). On the other hand, voicing is more extensive in Peninsular dialects spoken around Toledo, Ávila, and Cáceres. These varieties realize syllable-initial sibilants as voiced after voiced segments, and both has ido and ha sido are pronounced with a voiced sibilant.

Recent work in DT has sought to explain historical developments involving changes in place of articulation of sibilant consonants in several languages (see Itô \& Mester, in press, on Japanese and Padgett \& Zygis 2003 on Polish and Russian). Following Flemming's $(1995,2002)$ framework, which assumes no inputs or faithfulness constraints, Baker (2003) is the first to apply DT to the Spanish sibilants, analyzing primarily the changes in place of articulation that occurred in the early modern period subsequent to voicing neutralization. We follow Baker in approaching Spanish sibilants in this way, although our analysis deals specifically with the contextual realizations of sibilant voice. Also, we more closely follow the version of DT developed by Padgett $(2003 a, b, c)$, which assumes input-output mappings and a division between lexical and postlexical rankings. We show that better descriptive coverage can be gained by distinguishing between obstruents that are phonologically specified as plus or minus [voice] and those that are neutral, or phonetically targetless, with respect to this feature (Ernestus 2003, Steriade 1997). Gradient and variable voicing effects observed in contemporary Spanish sibilants are explained by the interpolation of adjacent glottal activity through the constriction period of sibilants marked as neutral by the grammar. Synchronic and diachronic patterns are accounted for in terms of different rankings of universal but violable constraints. The loss of distinctively voiced sibilants in medieval Spanish correlates with the higher ranking of a positional markedness constraint requiring syllableinitial sibilants to be [-voice]. In addition, our analysis shows that systemic faithfulness and markedness constraints are necessary in addition to the standard faithfulness and markedness constraints of OT. Interacting with positional devoicing at the postlexical level, systemic faithfulness accounts for cases of word-final prevocalic sibilant voicing in a way that input-output faithfulness cannot. Because systemic markedness directly governs the well-formedness of contrasts, the ternary distinction in sibilant voicing can be incorporated into the phonology without overgenerating a universally unattested three-way surface contrast.

This paper is organized as follows. In Section 2, we trace the development of Spanish sibilants from the medieval period to modern varieties. In Section 3, we propose a DT account of the sound changes involving sibilant voicing, and 
in Section 4 we extend the analysis to cover contemporary developments. Section 5 discusses some theoretical implications of the proposed analysis and compares it to alternative accounts. Section 6 summarizes and concludes.

\section{Sibilant voicing patterns in Spanish}

There is a substantial body of research dealing with the development of the sibilant system in Spanish (Ford 1900, Espinosa 1935, Montoliu 1945, Joos 1952, Jungeman 1955, Catalán 1957, Dámaso Alonso 1962, Galmés de Fuentes 1962, Amado Alonso 1967, 1969, Martinet 1955, Malkiel 1971, Lantolf 1974, 1979, Kiddle 1977, Lloyd 1987, Harris-Northall 1992, Salvador \& Ariza 1992, Pensado 1993, and Penny 1993, 2002, among others). In this section, we first present the major diachronic stages involving voiced and voiceless sibilants, beginning with the medieval period. Then, we document cases of sibilant voicing in modern highland Ecuadorian and central Peninsular Spanish.

\subsection{Medieval Spanish}

There were three cognate pairs of sibilants in medieval Spanish: the dental affricates $/ \mathrm{t}^{\mathrm{s}} /$ and $/ \mathrm{d}^{\mathrm{z}} /$, the apicoalveolar fricatives $/ \mathrm{s} /$ and $/ \mathrm{z} /$, and the prepalatal fricatives $/ \mathrm{J} /$ and $/ 3 /$. Because $/ \mathrm{d}^{\mathrm{z}} /$ and $/ \mathrm{z} /$ evolved from the voicing of $/ \mathrm{t}^{\mathrm{s}} /$ and /s/ between vowels and /3/ developed from the word-medial groups /k'1/, /g'l/, and $/ \mathrm{j} /$, the voiced sibilants rarely occurred outside of the intervocalic environment. The minimal pairs in (1), taken from Penny (1993:82), illustrate the intervocalic voicing opposition, along with corresponding orthographic forms:

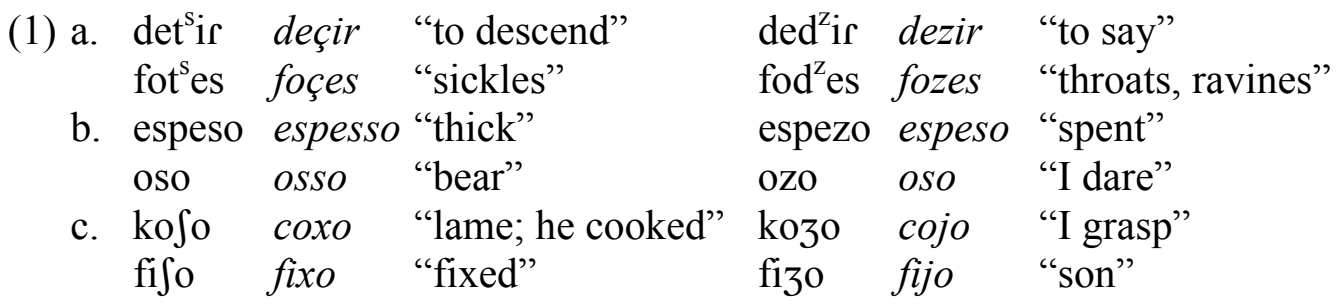

Voiced and voiceless sibilants did not contrast word-initially as the vast majority of everyday vocabulary items contained only voiceless sibilants in this position. /z/ never occurred word-initially, while only a limited number of learned words and borrowings from Arabic and Gallo-Romance began with either $/ \mathrm{d}^{\mathrm{z}} /$ or $/ 3 /$ (Alarcos Llorach 1988, Penny 1993). Syllable-final sibilants were represented only by the graphemes $\langle z\rangle,\langle s\rangle$ and $\langle x\rangle$. As shown by the plural forms in (2), intervocalic $\left\langle_{z}\right\rangle$ and $\left\langle_{s}\right\rangle$ corresponded to the voiced sounds $/ \mathrm{d}^{\mathrm{z}} /(2 \mathrm{a})$ and $/ \mathrm{z} /(2 \mathrm{~b})$, respectively, while intervocalic $\langle x>$ stood for the voiceless / $/$ / (2c) (Penny 1993:79). 
(2)

\begin{tabular}{|c|c|c|c|}
\hline \multirow{3}{*}{ 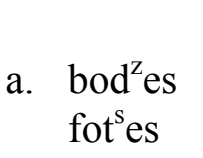 } & Plural & Singular & \\
\hline & vozes & voz & "voice(s)" \\
\hline & foçes & $f_{O z}$ & "sickle(s)" \\
\hline b. mezes & meses & mes & "month(s)" \\
\hline mjeses & miesses & mies & "ripe corn" \\
\hline c. linazes & linages & linax & "lineage(s)" \\
\hline kara $a$ es & caraxes & $\operatorname{carax}$ & "quiver(s)" \\
\hline
\end{tabular}

The orthographic mixture of final $\langle z\rangle,\langle s\rangle$, and $\langle x\rangle$ in the singular forms is generally interpreted as evidence that the sibilant voicing contrast was neutralized in syllable-final position. Although it is impossible to know with certainty how coda sibilants were pronounced in the Middle Ages, comparison with modern Ibero-Romance varieties gives some insight into how they might have been realized. In contemporary Spanish varieties that retain syllable-final lingual fricatives, regressive voicing assimilation before consonants is the norm. Furthermore, most contemporary studies of Spanish voicing assimilation describe the process as stylistically determined, gradient, and variable (Harris 1969, Hooper 1972, and Navarro Tomás 1977, among others). The following examples show modern sibilant voicing before voiced consonants (3a) and voiceless realizations before voiceless consonants $(3 \mathrm{~b})$, both within and across word boundaries.

$\begin{array}{llll}\text { (3) a. } \operatorname{des}^{\mathrm{z} \partial \mathrm{e}} & \sim \text { dezðe } & \text { desde } & \text { "since" } \\ \operatorname{las}^{\mathrm{z}} \text { ßakas } & \sim \text { laz } \text { Rakas } & \text { las vacas } & \text { "the cows" } \\ \text { b. este } & & \text { este } & \text { "this" } \\ \text { las kasas } & & \text { las casas } & \text { "the houses" }\end{array}$

Consequently, we follow Penny (1993:80), who argues that "it is highly likely that the medieval sibilants adopted the voice-quality of the following syllableinitial consonant (where this existed, either in the same word as the sibilant or at the beginning of the following word)."

The first change observed in the medieval sibilant system was the deaffrication of the dental phonemes in (1a) and (2a). According to Harris-Northall (1992), deaffrication began to affect syllable-final $/ \mathrm{t}^{\mathrm{s}} /$ and $/ \mathrm{d}^{\mathrm{z}} /$ by the midthirteenth century, after apocope had left many affricate segments in word-final position. Therefore, the $\langle z>$ of $v o z$ "voice" and foz "sickle" in (2a) most likely denotes the neutralization of manner as well as voice, yielding the dental fricative [s]. Subsequently, deaffrication was extended to syllable-initial position and, according to Lantolf $(1974,1979)$, may have been completed as early as the fourteenth century. The result of this consonantal weakening was a pair of dental fricatives distinguished by voicing, as in /desirir/ (</det ir $/)$ deçir "to descend" versus /dezir/ (</ded $\left.{ }^{\mathrm{i}} \mathrm{r} /\right)$ dezir "to say". 
It is difficult to tell how medieval word-final sibilants were realized in phrasal contexts other than preconsonantal. Since there was no graphemic distinction between voiced and voiceless sibilants in word-final position, as shown by the singular forms in (2), orthographic evidence is of no avail. Instead of merely speculating as to what these realizations might have been, we propose, again following Penny (1993), that some insight can be gained by observing similar varieties of modern Ibero-Romance. Catalan, Portuguese, and Judeo-Spanish all maintain a sibilant voicing distinction in their inventories, just like medieval Spanish. In these languages, word-final sibilants are voiced before a vowel-initial word and voiceless before pause, e.g., Portuguese asa[z]

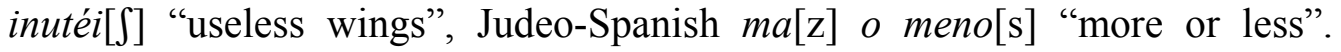
Penny (1993:80-81) argues that "[s]ince the medieval Castilian sibilant subsystem was similar in other regards [...] to that of Catalan, Portuguese, and Judeo-Spanish, it is likely that the similarity extended to having voiced wordfinal sibilants before a word-initial vowel." It is also likely that word-final sibilants were pronounced as voiceless in prepausal position.

\subsection{Early modern Castilian Spanish}

The next step in the simplification of the sibilant system was the devoicing of $/ z /, / z /$, and $/ 3 /$ and subsequent merger with their voiceless counterparts, as shown in (4). This innovation spread throughout what is today the Castilianspeaking area of the Iberian Peninsula during the fifteenth and sixteenth centuries.

$\begin{array}{rllll}\text { (4) a. } & / \mathrm{z} />/ \mathrm{s} / & \text { desic } & \text { dezir } & \text { "to say" } \\ \text { b. } & / \mathrm{z} />/ \mathrm{s} / & \text { oso } & \text { oso } & \text { "I dare" } \\ \text { c. } & / 3 />/ \text { S } / & \text { fijo } & \text { fijo } & \text { "son" }\end{array}$

Subsequent to this stage, all syllable-initial sibilants were realized as voiceless, whether intervocalic or word-initial. If medieval Spanish did show preconsonantal assimilation and prepausal devoicing, as suggested in Section 2.1, then it does not seem unreasonable to assume that these patterns continued through the early modern period, eventually giving rise to those observed in modern Spanish in (3). Absent from modern Castilian, however, is the voicing of wordfinal sibilants before a word-initial vowel. It is difficult to know the relative chronology of the change in (4) and the loss of voiced sibilants from wordfinal prevocalic contexts. (We return to the chronology of devoicing in Section 3.3., which explores the implications of a model that distinguishes between lexical and postlexical phonology in OT.)

Additional changes in the Spanish sibilant inventory occurred during the sixteenth and seventeenth centuries. In Northern Spain, the dental fricative $/ \mathrm{s} /$ developed into a non-sibilant interdental $/ \theta /$, while the prepalatal $/ \delta /$ became 
the velar $/ \mathrm{x} /$ and, therefore, also lost its sibilant character. In Andalusia, the dental and alveolar fricatives merged, usually producing a dorsoalveolar outcome (seseo), but in some areas the dental fricative dominated, subsuming the $/ \mathrm{s} /$ (сесеo). Here also, the velar $/ \mathrm{x} /$ replaced the prepalatal $/ \mathrm{S} /$. As a result of these changes, modern Spanish retains only a single /s/ in its sibilant inventory, which is apicoalveolar in Northern Spain and dorsoalveolar in most of Andalusia and Latin America.

\subsection{Modern sibilant voicing in highland Ecuador and central Spain}

Voicing has never recovered its status as a lexically contrastive feature for intervocalic sibilants in modern Spanish. However, the existence of voiced allophones has been documented in contexts other than before voiced consonants. In the highland Ecuadorian varieties spoken around Quito and Cuenca, sibilant voicing serves a limited contrastive function in intervocalic contexts at the phrasal level (Lipski 1989, Robinson 1979, and Toscano Mateus 1953). In central Peninsular dialects spoken near Toledo, Ávila, and Cáceres, voicing is more extensive and affects any syllable-initial sibilant preceded by a voiced segment (Torreblanca 1978, 1986a,b). Scholars differ on whether Ecuadorian and Peninsular sibilant voicing should be considered archaic or innovative (see Section 4 for further discussion).

The highland Ecuadorian data in (5a) show that only [s] appears in wordmedial and word-initial intervocalic contexts. In $(5 \mathrm{~b})$, variable and gradient voicing occurs in coda position before a following voiced consonant both within and across words. Thus far, highland Ecuadorian Spanish parallels modern Castilian Spanish.

\begin{tabular}{|c|c|c|c|c|c|}
\hline ) a. & kasa & & *kaza & casa & "house" \\
\hline & no se & & *no ze & no sé & "I don't know" \\
\hline & $\operatorname{des}^{z} \partial \mathrm{e}$ & $\sim$ & dezðe & desde & "since" \\
\hline & $\operatorname{las}^{z}$ ßakas & $\sim$ & laz ßakas & las vacas & "the cows" \\
\hline
\end{tabular}

As originally noted by Robinson (1979:141) and subsequently confirmed by Lipski (1989:54), voicing can affect word-final sibilants before hesitation pauses in highland Ecuadorian Spanish. In (6a), the speaker pauses to complete a thought or access a lexical item and then continues the utterance. Prepausal [z] may occur even if the sentence is not actually completed, as in (6b). The example in (6c) shows that [z] appears even before true pauses (i.e., following a descending, phrase-final intonational contour), although this occurs less frequently. 
(6) a. de lo[z] ... comerciantes todos $l o[\mathrm{z}]$... profesionales

b. es, digamo $[\mathrm{z}] \ldots$ yo tenía pue[z] ...

c. lo suficientemente capa[z]. "of the ... business owners"

"all the ... professionals"

"it's, let's say ..."

"I had then ..."

"sufficiently capable"

Finally, the data in (7) show that word-final prevocalic sibilants routinely surface as $[\mathrm{z}]$ before a following vowel-initial word.

$$
\begin{array}{lll}
\text { loz otros } & \text { los otros } & \text { "the others" } \\
\text { ez el } & \text { es él } & \text { "it's he" } \\
\text { pwez en } & \text { pues en } & \text { "well, in" } \\
\text { erez un } & \text { eres un } & \text { "you are (a)n" }
\end{array}
$$

Lipski (1989:53-54) describes voicing in this context as very stable, noting that it is independent of both speech rate and style and occurs even in very slow, emphatic speech. A comparison of the intervocalic sibilants in (5a) with those in (7) shows that voicing applies only at the word boundary, apparently as a signal of the sibilant's word-final status. In fact, word-final prevocalic voicing functions to preserve a surface contrast between underlyingly distinct phrases in a manner similar to that hypothesized for medieval Spanish in Section 2.1. As both Lipski and Robinson make clear, native speakers do perceive a difference between phrases such as those in (8). ${ }^{1}$

$$
\begin{array}{lll}
\text { az iðo } & \text { has ido } & \text { "you have gone" } \\
\text { a siðo } & \text { ha sido } & \text { "s/he, it has been" }
\end{array}
$$

Finally, we turn to a cluster of Peninsular Spanish dialects in which sibilant voicing is more extensive than in highland Ecuador. Based on data collected during the 1970s, Torreblanca $(1978,1986 a, b)$ finds that informants from Toledo, Ávila, and Cáceres exhibit [z] not only in syllable-final position before voiced consonants as expected, but also in prevocalic position when preceded by a voiced segment. As in highland Ecuadorian Spanish, voicing is particularly likely to occur in word-final prevocalic position. However, the central Peninsular data in $(9 a, b)$ show that word-medial and word-initial sibilants are also voiced (cf. (5a)). Torreblanca also claims that [z] sometimes appears in prepausal position and even before voiceless consonants, although no specific examples of such productions are provided. 


$\begin{array}{llll}\text { (9) a. } & \text { gwezos } & \text { huesos } & \text { "bones" } \\ & \text { manzo } & \text { manso } & \text { "tame" } \\ \text { b. } & \text { pwe zi } & \text { pues si } & \text { "well, yes" } \\ \text { o zea } & \text { o sea } & \text { "that is" } \\ \text { aßer zi } & \text { a ver si } & \text { "let's see if" } \\ \text { en el zago } & \text { en el saco } & \text { "in the bag" }\end{array}$

Torreblanca's descriptions suggest that central Peninsular/s/-voicing exhibits all the characteristics of a phonetic-level phenomenon, as it is gradient, variable, and sensitive to phonetic context as well as speech rate and register. In most areas, [z] is most common in relaxed, rapid speech although in some villages it also appears even in more formal registers. Voicing is more common in intervocalic position, especially when both the flanking vowels are unstressed, than between a voiced consonant and a vowel. The overall degree of sibilant voicing is variable, with glottal tone present throughout the frication period of some tokens but observable only at the $\mathrm{VC}$ and $\mathrm{CV}$ margins of others.

\section{An account of Spanish sibilant voicing patterns in DT}

In Section 3.1, we make explicit our assumptions about the representation of sibilant voicing contrasts and the way in which such contrasts are regulated in a constraint-based grammar. We account for the patterns of sibilant voicing in medieval Spanish in Section 3.2 and for the loss of sibilant voicing contrast in Section 3.3.

\subsection{Representations and constraints}

We adopt the conventional distinction between categorical and gradient sound patterns. Following Cohn (1990), Keating (1988, 1990), and Liberman \& Pierrehumbert (1984), among others, we assume that categorical patterns reflect the realization of phonologically specified articulatory and perceptual targets, and that gradient effects arise through phonetic interpolation among adjacent targets. Furthermore, following Steriade (1997) and Ernestus (2003), we distinguish between phonologically contrastive obstruents, specified as either [+voice] or [-voice], and neutral obstruents, which are [0voice]. Distinctively voiced obstruents require specific articulatory gestures to ensure perception of their phonological category (Kirchner 1998, Westbury \& Keating 1986). For instance, phonologically voiceless obstruents between vowels require an active glottal abduction gesture to prevent the passive voicing that is typical of intervocalic position. Similarly, to counteract the natural tendency toward utterance-initial and utterance-final devoicing due to changes in transglottal pressure, phonologically voiced obstruents require some type of voicing-enabling gesture, such as intercostal contraction or oral cavity expansion. 
On the other hand, no articulatory gestures are made in order to realize neutral obstruents as voiced or voiceless because they need not be perceived as belonging to either category. "[N]eutralized obstruents are, in Keating's (1990) terms, targetless with respect to voicing: they assume the laryngeal posture of a neighboring sound" (Steriade 1997:22). Gradient voicing effects are expected in such cases, due to the interpolation of glottal activity from the surrounding context through the constriction period of the [0voice] obstruent.

For purposes of illustration, Figure 1 contrasts the realization of a neutral sibilant, represented typographically as [S], between a vowel and a voiced consonant (a) with that of phonologically voiceless [s] between two vowels (b). In both examples, solid horizontal lines denote glottal targets that correspond to phonologically specified [voice] features, and dotted lines show interpolation between targets. Since neutral [S] has no specified target, glottal vibration during the sibilant constriction period is determined by gradient interpolation between the preceding vowel and the following voiced consonant. As the dotted lines in (a) show, there is a range of possible trajectories that interpolation may follow. The realization of neutral [S] depends on phonetic factors such as sibilant duration and intensity, stress, adjacency to major prosodic boundaries, speech register, and speaking rate. Sibilants whose duration extends beyond certain durational thresholds tend to passively devoice for aerodynamic reasons, and voiceless fricatives are typically longer than voiced ones (Kirchner 1998:163, 236, Widdison 1997). Therefore, shorter constriction durations increase the probability of complete voicing throughout neutral [S], whereas longer durations favor gradient degrees of voicelessness. In contrast to the phonetically variable $[\mathrm{S}]$, the intervocalic [s] in (b) has a target for voicelessness because it is phonologically specified as [-voice]. Interpolation from the first vowel to the sibilant and from the sibilant to the second vowel produces transitional glottal vibration at the margins of the sibilant constriction. ${ }^{2}$
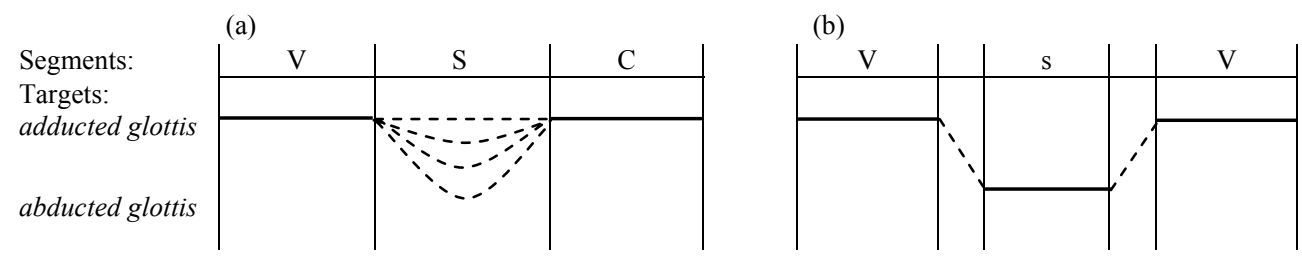

Figure 1: Variable and gradient sibilant voicing as interpolation between phonetic targets

As we will see in the analysis below, the advantage of assuming a ternary distinction for sibilant voicing is that it accounts for several gradient effects observed in different varieties of Spanish. While this representational assumption allows for an adequate phonetic description, it says nothing about why sibilants undergo voicing neutralization. Are sibilants neutral because they lack 
[voice] specifications, or do they lack [voice] specifications because they are neutral? The circularity is resolved by the fact that the grammar determines the surface distribution of sibilant voicing contrasts. We assume that the phonological grammar consists of ranked and violable constraints (Prince \& Smolensky 1993) and, furthermore, that some of these constraints require surface contrasts to be maintained and kept perceptually distinct (see Flemming 1995, 2002 and Padgett 2003a,b,c, as well as other works cited in Section 1).

In DT, contrast is a systemic notion requiring the evaluation not of isolated forms but of the larger system of contrasts in which those forms exist. In the present analysis, it is necessary only to consider the idealized forms shown in (10), which abstract away from place and continuancy distinctions and show [-voice], [0voice], and [+voice] sibilants occurring in different contexts, namely intervocalic (10a), postpausal (10b), prepausal (10c), and preconsonantal (10d).
a. $\mathrm{VsV}$ VSV $\mathrm{VzV}$
c. Vs VS $\mathrm{Vz}$
b. $\mathrm{sV} \quad \mathrm{SV} \quad \mathrm{zV}$
d. $\mathrm{VsC}$ VSC $\mathrm{VzC}$

These forms constitute a 'mini-language' of twelve idealized words, collectively representing all that is relevant to the analysis of sibilant voicing patterns. For example, it does not matter what the flanking vowels are in (10a) nor what other segments might lie beyond the immediately adjacent vowels. The idealized word VsV corresponds to actual words such as medieval Spanish [det'ir] deçir "to descend", [oso] osso "bear", and [fifo] fixo "fixed", while $\mathrm{VzV}$ denotes [ded ${ }^{\mathrm{z} i}$ ] dezir "to say", [ozo] oso "I dare", and [fizo] fijo "son". On the other hand, VSC in (10d) corresponds to actual words such as modern Spanish [este] este "this" and [des ðe $\sim$ dezðe] desde "since", where gradient voicing in the latter stems from interpolation, as in Figure 1.

OT's tenet of Richness of The Base (Prince \& Smolensky 1993) forbids placing any language-specific restrictions on input representations, which means that all of the idealized words in (10) must be considered as possible inputs. ${ }^{3}$ In the version of DT assumed here, the standard markedness and faithfulness constraints of OT work together with systemic constraints on contrast to determine which input-output mappings are optimal in a given language. Our analysis incorporates the following faithfulness constraints:

(11) a. IDENTSIB(voice) Corresponding input and output sibilants are identical in [voice].

b. *Merge No output word has multiple input correspondents.

It is typically assumed that contrast in OT is guaranteed by input-output correspondence constraints, such as the one in (11a), which enforce similarity be- 
tween single inputs and their corresponding outputs (McCarthy \& Prince 1995). *MERGE in (11b) extends this notion of faithfulness to sets of inputoutput mappings. The constraint is reminiscent of UNIFORMITY (McCarthy \& Prince 1995), which disfavors the coalescence of two input segments into one output segment. However, *MERGE applies to whole words.

Putting aside the form VSV for the moment, consider the mappings in (12), where subscripts are used to identify the individual words $\mathrm{VsV}$ and $\mathrm{VzV}$ from (10a).
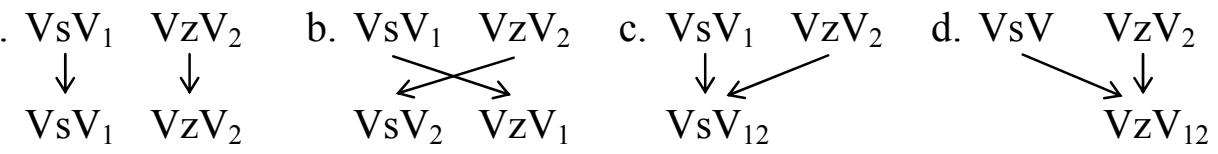

The fully faithful mapping in (12a) satisfies IDENTSIB(voice), because corresponding input and output sibilants have the same voicing specification, and *Merge, because each output word has a single corresponding input. (12b) shows that IDENTSIB(voice) is necessary in addition to *MERGE in order to rule out switches of input voicing values. Since a surface contrast between words is maintained, *MERGE alone cannot rule out the mapping in (12b). (We will see in Section 5 that *MERGE is nonetheless crucial in accounting for the voicing of word-final prevocalic sibilants in both medieval and modern Ecuadorian Spanish.) Finally, (12c,d) violate both IDENTSIB(voice), because one input sibilant in each case changes its voicing value in the output, and *MERGE, because the output words have multiple corresponding inputs.

DT also incorporates systemic markedness constraints that require a minimal degree of perceptual distinctiveness among contrasting words along some phonetic dimension. It is well known that perceptibility of a given contrast varies as a function of the number of perceptual cues available in different phonetic contexts (see Steriade 1997, among others). As Widdison (1997) notes, the presence of glottal tone during the constriction period of a sibilant is in itself an unreliable cue to sibilant voicing contrast because voiced sibilants are often passively devoiced for aerodynamic reasons (see also Kirchner 1998:163). Evidence from acoustic studies, summarized in Table 1, suggests a number of other cues that are relevant to the categorization of sibilants as phonologically voiceless or voiced. Internal cues reside during the period of oral constriction of the sibilant, whereas transitional cues are spread across the external context in which the sibilant appears. 


\begin{tabular}{|c|c|c|}
\hline Cue type & Perceptual cue & Sources \\
\hline Internal & $\begin{array}{l}\text { 1. Degree of glottal tone } \\
\text { 2. Duration of sibilant noise } \\
\text { 3. Intensity of sibilant noise }\end{array}$ & $\begin{array}{l}\text { Cole \& Cooper (1975), Denes (1955), Haggard } \\
\text { (1978), Massaro \& Cohen }(1977), \text { Smith } \\
\text { (1997), Widdison }(1995,1996,1997)\end{array}$ \\
\hline Transitional & $\begin{array}{l}\text { 1. F1 transitions at V-C and } \mathrm{C}-\mathrm{V} \text { boundaries } \\
\text { 2. Voice Onset Time } \\
\text { 3. F0 of following vowel } \\
\text { 4. Duration of preceding vowel }\end{array}$ & $\begin{array}{l}\text { Chen (1970), Jongman (1989), Massaro \& } \\
\text { Cohen (1977), Stevens et al. (1992) }\end{array}$ \\
\hline
\end{tabular}

Table 1: Perceptual cues to phonological sibilant voicing contrast

Sibilant voicing contrasts are perceptually most distinct in intervocalic position because the flanking vowels provide an optimal acoustic backdrop against which to perceive the beginning, medial, and end portions of sibilant noise, thereby favoring both the internal and transitional cues. In contrast, only one vowel is adjacent to sibilants appearing next to a word boundary or consonant, which reduces the number of transitional cues and renders the contrast less perceptible. The superiority of intervocalic position can be captured formally in DT by the systemic markedness constraint in (13):

SPACE $_{\mathrm{SV}}$ Potential minimal pairs differing in sibilant voicing differ at least as much as $[\mathrm{s}]$ and $[\mathrm{z}]$ do between vowels.

'Potential minimal pairs' are defined as any two words from the set in (10) that are identical except for one segment, such as $\mathrm{VsV}-\mathrm{VzV}, \mathrm{VS}-\mathrm{Vz}$, etc. SPACE $_{S V}$ requires that a sibilant voicing contrast be at least as perceptually distinct as it is when the relevant segments appear in intervocalic position, which offers the maximum number of perceptual cues. Although (13) suffices for an analysis of Spanish, this constraint is actually part of a larger hierarchy of SPACE constraints on sibilant voicing contrasts (see Section 5).

How do systemic constraints on perceptual distinctiveness evaluate neutral [S], given that it lacks any articulatory/perceptual target for voicing? If interpolation favors substantial glottal adduction throughout the sibilant constriction in VSV, then we would expect this form to resemble an intervocalic sibilant that is phonologically specified as [+voice]. However, VSV and VzV may still differ with respect to perceptual cues other than glottal tone, such as intensity of sibilant noise, duration of the preceding vowel, etc. (see Table 1). The contrast between $\mathrm{VsV}$ and $\mathrm{VzV}$ is maximally dispersed, whereas the contrasts between VsV and VSV and between VSV and VzV fail to achieve the same degree of perceptual distinctiveness. ${ }^{4}$

In Tableau 1, candidates (a), (b), and (c) violate SPACE Sv $_{\text {because they con- }}$ tain suboptimal contrasts. Note that candidate (a) incurs two violations, one for the VsV - VSV contrast and another for VSV - VzV. Candidate (d) does have a perceptually sufficient intervocalic contrast, while candidate (e) vacuously satisfies SPACE Sv because there is no potential minimal pair to evaluate. Finally, candidates (f) and (g) show that a contrast between [s] and [z] is not per- 
ceptually distinctive enough in word-initial and preconsonantal contexts, respectively, due to the reduced number of transitional cues available in these positions. Both candidates violate $\mathrm{SPACE}_{\mathrm{SV}}$, which requires sibilant voicing contrasts to be at least as perceptible as it is in the cue-rich intervocalic context.

\begin{tabular}{|c|c|c|c|}
\hline & & & SPACE $_{\mathrm{SV}}$ \\
\hline a. $\mathrm{VsV}$ & VSV & $\mathrm{VzV}$ & $* ! *$ \\
\hline b. VsV & VSV & & $* !$ \\
\hline c. & VSV & $\mathrm{VzV}$ & $* !$ \\
\hline d. VsV & & $\mathrm{VzV}$ & \\
\hline e. VsV & & & \\
\hline f. sV & & $\mathrm{zV}$ & *! \\
\hline g. VsC & & $\mathrm{VzC}$ & $* !$ \\
\hline
\end{tabular}

Tableau 1: Evaluation of potential minimal pairs by systemic markedness

Finally, our analysis incorporates two non-systemic markedness constraints, one positional and the other context-free:

(14) a. $\sigma[\mathrm{s}$

A sibilant in syllable-initial position is [-voice].

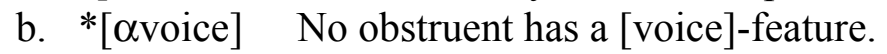

(14a) requires any sibilant appearing in onset position in the output to be voiceless. This constraint achieves a type of positional augmentation in the sense of Smith (2002), who shows that languages sometimes neutralize contrasts even in phonologically strong positions. When this happens, the outcome of neutralization always involves a perceptual augmentation whereby some perceptually enhancing element occupies the phonologically strong position. Due to their typically longer duration and higher noise intensity, voiceless sibilants are more perceptually salient than their voiced counterparts (Smith 1997, Widdison 1997). Also, syllable-initial position has been well documented as phonologically strong (see Beckman 1997, 1998). ${ }^{5}$ Given our representational assumptions, it is not feasible to think of sibilant devoicing as a particular instantiation of a more general markedness constraint banning obstruents that are [+voice]. Such a constraint fails to rule out syllable-initial neutral [S], which could be phonetically voiced in highly sonorous environments due to interpolation.

The constraint in (14b) encodes the articulatory markedness of sibilants that are phonologically specified as either [+voice] or [-voice]. These sibilants require specific articulatory gestures to ensure the perception of their phonological category, and such gestures presumably involve some degree of effort cost. In contrast, neutral sibilants have no specified target for glottal adduction or abduction, and the glottis is free to take positions required for the realizations of surrounding segments. Whereas [s] and [z] each violate (14b), neutral [S] satisfies the constraint. 


\subsection{Analysis of medieval Spanish sibilants}

Tableau 2 includes the input words VsV, VSV, and VzV, taken from the set in (10a), in which all three types of sibilant appear between vowels. Since VSV does not form a sufficient contrast with either $\mathrm{VsV}$ or $\mathrm{VzV}$, SPACE sv $_{\text {s }}$ must dominate *MERGE in order to rule out the fully faithful candidate (a) and the insufficiently dispersed contrast in (b). (To save space, we omit candidates like (a) and (b) from subsequent tableaux.) *MERGE eliminates candidates (e-g) because they neutralize too much. Candidates (c) and (d) tie on the remaining constraints and are therefore co-optimal, differing only in the mapping of input VSV. Since both candidates present a maximally dispersed sibilant voicing contrast, either outcome seems equally plausible in theory. For medieval Spanish, *Merge must dominate both $\sigma[\mathrm{s}$ and $*$ [ $\alpha$ voice], otherwise the sibilant voicing contrast would be neutralized between vowels. ${ }^{6}$

\begin{tabular}{|ccc||c|c|c|c|c|}
\hline $\mathrm{VsV}_{1}$ & $\mathrm{VSV}_{2}$ & $\mathrm{VzV}_{3}$ & SPACE $_{\mathrm{SV}}$ & $*$ MERGE & $\sigma[\mathrm{s}$ & $*[\alpha$ voice $]$ & IDENTSIB(voice) \\
\hline \hline a. $\mathrm{VsV}_{1}$ & $\mathrm{VSV}_{2}$ & $\mathrm{VzV}_{3}$ & $* ! *$ & & $* *$ & $* *$ & \\
\hline b. $\mathrm{VsV}_{1}$ & $\mathrm{VSV}_{23}$ & & $* !$ & $*$ & $*$ & $*$ & $*$ \\
\hline c. $\mathrm{VsV}_{12}$ & & $\mathrm{VzV}_{3}$ & & $*$ & $*$ & $* *$ & $*$ \\
\hline d. $\mathrm{VsV}_{1}$ & & $\mathrm{VzV}_{23}$ & & $*$ & $*$ & $* *$ & $*$ \\
\hline e. $\mathrm{VsV}_{123}$ & & & & $* * !$ & & $*$ & $* *$ \\
\hline f. & $\mathrm{VSV}_{123}$ & & & $* * !$ & $*$ & & $* *$ \\
\hline g. & & $\mathrm{VzV}_{123}$ & & $* * !$ & $*$ & $*$ & $* *$ \\
\hline
\end{tabular}

Tableau 2: Word-medial intervocalic contrast (medieval Spanish)

The analysis in Tableau 2 captures the generalization that medieval Spanish words could be contrastive based on a difference between intervocalic voiceless and voiced sibilants. Accidental gaps in the lexicon are, of course, possible. As in any generative framework, the goal of DT is to derive all and only the possible words of a given language. The advantage of assuming idealized candidates is that it focuses the analysis on only those aspects that are relevant, which is something phonologists already do (Padgett 2003a,b,c).

Tableau 3 illustrates the analysis of word-initial position, from which voiced sibilants were absent in patrimonial medieval Spanish. ${ }^{7}$ Since SPACE requires a sibilant voicing contrast to be at least as distinct as $[\mathrm{s}]$ and $[\mathrm{z}]$ are between vowels, candidates (a) and (b) are ruled out because they attempt the contrast in a less perceptible non-intervocalic context. The remaining candidates (c-e) all tie on *MERGE, and $\sigma[\mathrm{s}$ optimizes the phonologically voiceless sibilant in (c). Recall from the discussion at the beginning of Section 3.1 that obstruents naturally tend to devoice at utterance edges due to the equalization of transglottal pressure. If neutral [S] adopts the least marked laryngeal setting as a function of phonetic context, the word-initial [S] in candidate (d) would be realized as phonetically voiceless after pause, yielding a result that is ultimately identical to the phonologically voiceless [s] in candidate (c). As we will see below, however, evidence from the phrasal behavior of medieval sibilants actually requires a phonologically voiceless $[\mathrm{s}]$ in word-initial position. For the 
moment, let us assume that $\sigma_{[}[\mathrm{s}$ outranks $*[\alpha$ voice $]$ in order to ensure $\mathrm{sV}$ in (c) over SV in (d).

\begin{tabular}{|c|c|c|c|c|c|c|c|}
\hline $\mathrm{sV}_{1}$ & $\mathrm{SV}_{2}$ & $\mathrm{zV}_{3}$ & SPACE $_{S V}$ & *MERGE & ${ }_{\sigma}[\mathrm{s}$ & $*[\alpha$ voice $]$ & IDENTSIB(voice) \\
\hline a. $\mathrm{sV}_{12}$ & & $\mathrm{zV}_{3}$ & *!! & * & "* & $* *$ & $*$ \\
\hline b. $\mathrm{sV}_{1}$ & & $\mathrm{zV}_{23}$ & $* !$ & $*$ & * & ** & $*$ \\
\hline c. $\mathrm{sV}_{123}$ & & & & ** & & * & ** \\
\hline d. & $\mathrm{SV}_{123}$ & & & $* *$ & $* !$ & & ** \\
\hline e. & & $\mathrm{zV}_{123}$ & & *** & $* !$ & * & ** \\
\hline
\end{tabular}

Tableau 3: Word-initial sibilants are [-voice] (medieval Spanish)

The analysis of preconsonantal sibilants is given in Tableau 4. For reasons

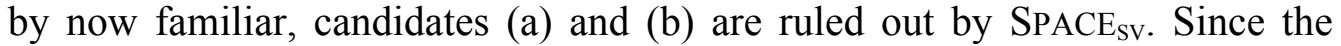
sibilants in (c-e) are not syllable-initial, $\sigma[\mathrm{s}$ is irrelevant. The decision is passed to $*$ [ $\alpha$ voice], which favors neutral [S] in (d) over sibilants with a phonological specification for voicing in (c) and (e). As explained in Figure 1 and the surrounding discussion, preconsonantal $[\mathrm{S}]$ is subject to gradient voicing as a function of interpolation from the phonetic context, as in modern Spanish [des ððe $\sim \operatorname{dez} \circlearrowright \mathrm{e}]$ desde "since".

\begin{tabular}{|c|c|c|c|c|c|c|c|}
\hline $\mathrm{VsC}_{1}$ & $\mathrm{VSC}_{2}$ & $\mathrm{VzC}_{3}$ & SPACE $_{\mathrm{SV}}$ & *MERGE & ${ }_{\sigma}[\mathrm{S}$ & $*[\alpha$ voice $]$ & IDENTSIB(voice) \\
\hline a. $\mathrm{VsC}_{12}$ & & $\mathrm{VzC}_{3}$ & $* !$ & $*$ & & $* *$ & $*$ \\
\hline b. $\mathrm{VsC}_{1}$ & & $\mathrm{VzC}_{23}$ & $* !$ & $*$ & & $* *$ & $*$ \\
\hline c. $\mathrm{VsC}_{123}$ & & & & $* *$ & & $* !$ & $* *$ \\
\hline d. & $\mathrm{VSC}_{123}$ & & & $* *$ & & & $* *$ \\
\hline e. & & $\mathrm{VzC}_{123}$ & & $* *$ & & $* !$ & $* *$ \\
\hline
\end{tabular}

Tableau 4: Preconsonantal sibilants are [0voice] (medieval Spanish)

As discussed in Section 2.1, Penny (1993:80-81) argues that in medieval Spanish, word-final sibilants most likely underwent regressive voicing assimilation before a following consonant-initial word, while they were probably realized as voiceless before pause and voiced before vowels. ${ }^{8}$ In analyzing the phrasal behavior of word-final sibilants, we assume a distinction between lexical and postlexical phonological levels in OT, which has been amply motivated by Itô \& Mester (2001), Kiparsky (1998), McCarthy \& Prince (1993), and Padgett (2003a,c), among others. As illustrated in Figure 2, Richness of The Base holds of inputs to the lexical phonology, while the input to the postlexical phonology is necessarily the output of the lexical phonology.

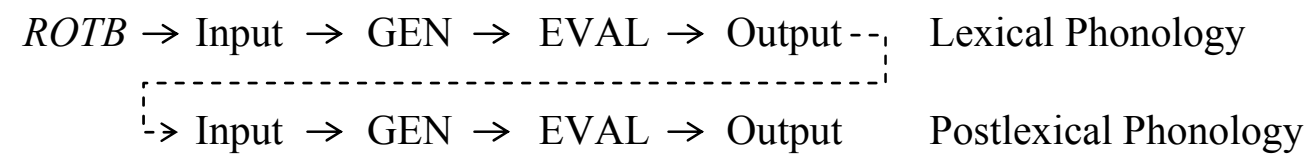

Figure 2: Lexical and postlexical phonologies in OT

Given the ranking already established above, the optimal lexical output for word-final position is VS (compare the optimal candidate (d), VSC, in Tableau 
4). In utterance-final position, neutral [S] will be gradiently realized as voiceless due to the equalization of transglottal pressure. An analysis of word-final preconsonantal sibilants requires us to consider $\mathrm{VS} \mid \mathrm{C}$ as a phrasal input to the postlexical component, where the vertical line denotes a word boundary. On the default assumption that the constraint ranking established for the lexical level also holds at the postlexical level, the outcome for word-final preconsonantal sibilants is the same as for word-internal ones shown in Tableau 4, with phonetic voicing assimilation occurring as a function of the following consonant, e.g., modern Spanish [las ${ }^{\mathrm{z}}$ ßakas laz ßakas] las vacas "the cows".

Interestingly, an account of word-final prevocalic $[z]$ in medieval Spanish follows from the analysis already established thus far. When a word-final sibilant appears before a vowel-initial word, this sequence forms a potential phrasal minimal pair with a word-initial sibilant appearing after a vowel-final word. Contemporary Spanish has ido "you have gone" versus ha sido "s/he, it has been" is one actual example of such a phrasal pair (although in modern Castilian the two phrases are in fact homophonous due to the lack of voiced sibilants-see Section 3.3). As we have seen above, the lexical phonology generates VS and $\mathrm{sV}$ as outputs, which then serve as inputs to the postlexical phonology. Tableau 5 illustrates the postlexical evaluation of these forms when the sibilants become intervocalic at the phrasal level, VS $\mid \mathrm{V}$ and V $\mid \mathrm{sV}$. In Spanish, word-final consonants resyllabify as the onset of a following vowel-initial word (Harris 1983:43-44). We assume that postlexical resyllabification is enforced by the constraint ONSET, not shown in this and subsequent tableaux. The contrast in (a) incurs a violation of SPACE $E_{S v}$ and is eliminated. *MERGE prevents neutralization in candidates (b) and (c), respectively. Since medieval Spanish lacks word-initial voiced sibilants, there is no input $\mathrm{V} \mid \mathrm{zV}$ to the postlexical phonology. Input VS|V can now map onto that space in (d) and, in fact, is compelled to do so by the postlexical ranking. Presumably, such a state of affairs would have allowed medieval Spanish speakers to maintain a contrast between underlyingly distinct phrases, which would correspond to the pronunciation of modern Spanish has ido and ha sido as [az iðo] and [a siðo], respectively. ${ }^{9}$ Just as candidate idealization admits accidental gaps in lexical outputs, the same is true of postlexical outputs. That is, mis abuelos "my grandparents" forms no phrasal minimal pair with *mi sabuelos because sabuelos is not an actual word in Spanish.

\begin{tabular}{|rl||c|c|c|c:c|}
\hline $\mathrm{VS} \mathrm{V}_{1}$ & $\mathrm{~V} \mid \mathrm{sV}_{2}$ & SPACE $_{\mathrm{SV}}$ & $*$ MERGE & $\sigma[\mathrm{s}$ & $*[\alpha$ voice & IDENTSIB(voice) \\
\hline \hline a. $\mathrm{VSV}_{1}$ & $\mathrm{VsV}_{2}$ & $* !$ & & $*$ & $*$ & $*$ \\
\hline b. $\mathrm{VSV}_{12}$ & & & $* !$ & $*$ & & $*$ \\
\hline c. & $\mathrm{VsV}_{12}$ & & $* !$ & & $*$ & $*$ \\
\hline d. $\mathrm{VzV}_{1}$ & $\mathrm{VsV}_{2}$ & & & $*$ & $* *$ & $*$ \\
\hline
\end{tabular}

Tableau 5: Phrasal intervocalic contrast (medieval Spanish, postlexical ranking) 


\subsection{Analysis of medieval Spanish sibilant devoicing}

Modern Castilian Spanish no longer allows intervocalic voiced sibilants either within or across words. We propose to account for the loss of sibilant voicing from syllable-initial position in terms of the re-ranking of $\sigma[\mathrm{s}$ above *Merge. In the lexical phonology of modern Castilian Spanish, such a ranking maps all intervocalic sibilants in the input to voiceless [s], as shown in Tableau 6 . The analysis of word-initial, preconsonantal, and word-final contexts remains the same as for medieval Spanish prior to devoicing, since the promotion of $\sigma_{\sigma}[\mathrm{s}$ does not change the optimality of outputs $\mathrm{sV}$, VSC, and VS, respectively. Postlexically, the same ranking neutralizes the sibilant voicing distinction in phrasal intervocalic contexts as well. In Tableau 7, the postlexical inputs $\mathrm{VS} \mid \mathrm{V}$ and $\mathrm{V} \mid \mathrm{sV}$ map to $\mathrm{VsV}$ in the output, which captures the fact that has $i d o$ and ha sido are homophonous in modern Castilian.

\begin{tabular}{|c|c|c|c|c|c|}
\hline $\mathrm{Vs}_{1}$ & $\mathrm{VSV}_{2} \quad \mathrm{VzV}_{3}$ & $\begin{array}{l:l}\operatorname{SPACE}_{\mathrm{SV}} & { }_{\sigma}[\mathrm{s} \\
\end{array}$ & *MERGE & $*[\alpha$ voice $]$ & IDENTSIB(voice) \\
\hline a. $\mathrm{VsV}_{12}$ & $\mathrm{Vzz}_{3}$ & : ${ }^{*} !$ & * & $* *$ & * \\
\hline b. $\mathrm{VsV}_{1}$ & $\mathrm{VzV}_{23}$ & $* !$ & $*$ & $* *$ & $*$ \\
\hline c. $\mathrm{VsV}_{123}$ & & 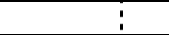 & ** & * & ** \\
\hline d. & $\mathrm{VSV}_{123}$ & *! & ** & & ** \\
\hline e. & $\mathrm{VzV}_{12}$ & $* !$ & ** & * & ** \\
\hline
\end{tabular}

Tableau 6: Word-medial intervocalic sibilants are [-voice] (modern Castilian, lexical ranking)

\begin{tabular}{|c|c|c|c|c|c|}
\hline $\mathrm{VS} \mid \mathrm{V}_{1}$ & $\mathrm{~V} \mid \mathrm{sV}_{2}$ & $\begin{array}{l:l}\text { SPACE }_{\mathrm{SV}} & \sigma\end{array}$ & *MERGE & $*[\alpha$ voice $]$ & IDENTSIB(voice) \\
\hline a. $\mathrm{VSV}_{1}$ & $\overline{\mathrm{VsV}_{2}}$ & $* ! \quad 1 \quad *$ & & $*$ & \\
\hline b. $\mathrm{VSV}_{12}$ & & 1 & * & & * \\
\hline c. & $\mathrm{VsV}_{12}$ & $\begin{array}{l}1 \\
1\end{array}$ & * & $*$ & $*$ \\
\hline d. $\mathrm{VzV}_{1}$ & $\mathrm{VsV}_{2}$ & $*$ & & ** & * \\
\hline
\end{tabular}

Tableau 7: Word-final intervocalic sibilants are [-voice] (modern Castilian, postlexical ranking)

According to Kiparsky $(1985,1995)$, sound changes first enter the grammar through the postlexical phonology but may then move up the grammar by entering the lexical phonology (see also Padgett 2003a). Consider the diachrony of sibilant devoicing proposed in Figure 3, which shows only the outputs generated by the lexical and postlexical rankings at different stages. Recall that the output of the lexical phonology serves as the input to the postlexical phonology. Medieval Spanish (Stage 1) allows intervocalic voiced sibilants both medially and finally, as shown in Section 3.2. Devoicing first enters the post-lexical phonology (Stage 2.1), in which the ranking of $\sigma[\mathrm{s} » *$ MerGE maps the non-voiceless sibilants of the lexical output onto their voiceless counterparts in the postlexical output. During this initial stage, sibilant voicing is still lexically contrastive in word-medial intervocalic position, but postlexically there is incipient devoicing of all syllable-initial sibilants. Ultimately, devoicing is 'promoted' to the lexical phonology (Stage 2.2), and word-medial voiced 
sibilants are no longer permissible in the lexical inventory. At this point, sibilant voicing has lost its status as a lexically contrastive feature, and word-final prevocalic sibilants are voiceless, as shown in Tableau 6 and Tableau 7, respectively.

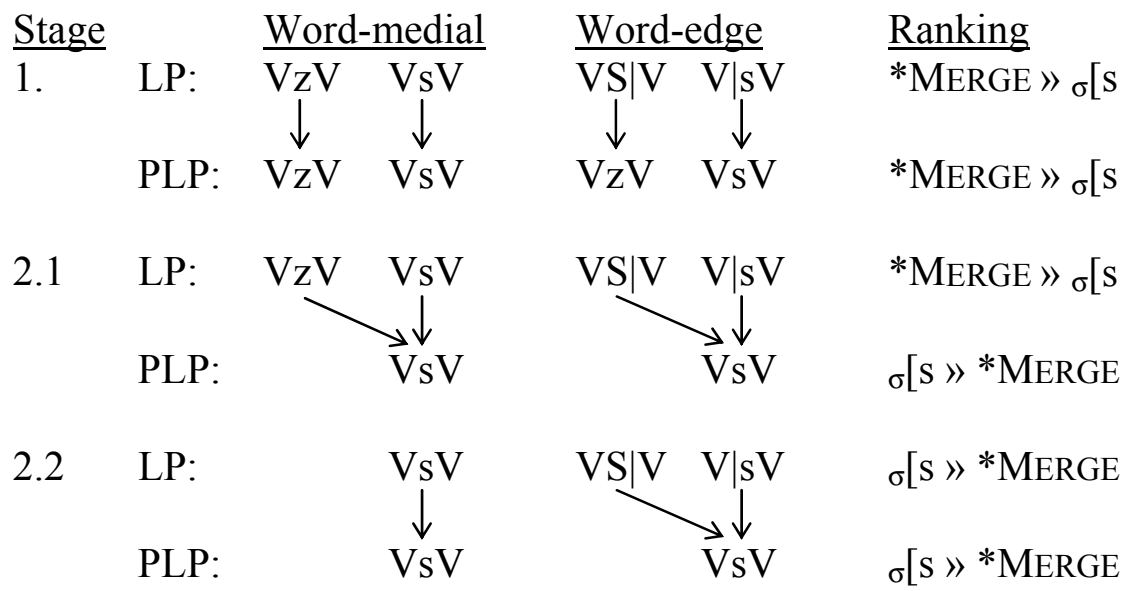

Figure 3: Proposed chronology of sibilant devoicing from medieval to modern Castilian Spanish

\section{Sibilant voicing in contemporary Spanish dialects}

The reemergence of sibilant voicing in highland Ecuadorian and central Peninsular Spanish can be accounted for with a minimal re-ranking of the constraints employed in the analysis put forth in Section 3. A crucial observation with respect to the highland Ecuadorian pattern is that sibilant voicing before voiced consonants is both variable and gradient, while voicing in word-final prevocalic position is categorical, independent of speech rate and style, and contrastive with respect to phrases (Lipski 1989). This strongly suggests that voicing in the former case is phonetic, arising through gradient interpolation of glottal activity through the constriction period of phonetically targetless [S], while voicing in the latter presumably reflects a phonological [+voice] specification. These facts are easily accommodated in a DT analysis that assumes a division between lexical and postlexical components. Like modern Castilian, highland Ecuadorian Spanish ranks $\sigma_{\sigma}[\mathrm{s}$ above * Merge in the lexical phonology, thereby ensuring the absence of distinctively voiced syllable-initial sibilants in (5a). As illustrated in Tableau 8, the Ecuadorian grammar has come to demote $\sigma$ [s postlexically, thereby loosening the requirement that all syllableinitial sibilants be [-voice]. However, word-final prevocalic /S/ cannot survive in (a) because SPACE $E_{\mathrm{SV}}$ eliminates the insufficiently dispersed contrast. Since word-initial [z] is not allowed at the lexical level, /S/ can map to [z] postlexically. *Merge favors this mapping in (d) over the neutralization mappings in 
(b) and (c), thereby preserving the contrast between underlyingly distinct phrases.

\begin{tabular}{|rr||c|c|c|c:c|}
\hline $\mathrm{VS} \mathrm{V}_{1}$ & $\mathrm{~V} \mid \mathrm{sV}_{2}$ & SPACE $_{\mathrm{SV}}$ & *MERGE & ${ }_{\sigma}[\mathrm{s}$ & $*[\alpha$ voice $]$ & IDENTSIB(voice) \\
\hline \hline a. $\mathrm{VSV}_{1}$ & $\mathrm{VsV}_{2}$ & $* !$ & & $*$ & $*$ & $*$ \\
\hline b. $\mathrm{VSV}_{12}$ & & & $* !$ & $*$ & & $*$ \\
\hline c. & $\mathrm{VsV}_{12}$ & & $* !$ & & $*$ & $*$ \\
\hline d. $\mathrm{VzV}_{1}$ & $\mathrm{VsV}_{2}$ & & & $*$ & $* *$ & $*$ \\
\hline
\end{tabular}

Tableau 8: Phrasal intervocalic contrast

(highland Ecuadorian, postlexical ranking)

One of the main arguments in favor of a DT approach to sibilant voicing is that it makes a principled connection between lexical and postlexical intervocalic contrast. It is no coincidence that contrastive [z] in Ecuadorian Spanish reappears in precisely the same segmental context in which $[\mathrm{s}]$ and $[\mathrm{z}]$ were contrastive in medieval Spanish. As we have seen, intervocalic position provides the largest number of perceptual cues in support of the distinction between voiced and voiceless sibilants. As shown in Tableau 8, the postlexical $/ \mathrm{S} / \rightarrow[\mathrm{z}]$ mapping is required in order to maintain a contrast between phrases and to satisfy the perceptual requirements of SPACE ${ }_{\mathrm{Sv}}{ }^{10}$ In other contexts, such as preconsonantal $(5 b)$, neutral $[\mathrm{S}]$ is subject to phonetic voicing as expected. To account for the variable appearance of [z] before hesitation pauses in $(6 \mathrm{a}, \mathrm{b})$ and for the much rarer phrase-final $[\mathrm{z}]$ in $(6 \mathrm{c})$, we suggest that phonetic voicing in these cases stems from the maintenance of glottal vibration from the preceding vowel through the constriction period of targetless [S].

We turn now to the central Peninsular Spanish data. The greater number of contexts of sibilant voicing and the decidedly phonetic nature of the process (recall the discussion surrounding (9)), both suggest that in this variety, neutral $[\mathrm{S}]$ is preferred across the board, even in those syllable-initial contexts where modern Castilian and highland Ecuadorian Spanish have a phonologically

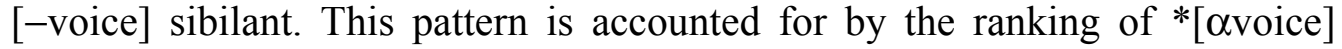
above both $\sigma[\mathrm{s}$ and the faithfulness constraints *MERGE and IDENTSIB(voice). Such a ranking must hold at least postlexically, but there is no reason not to

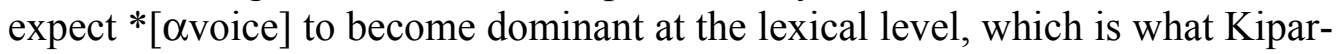
sky's model of sound change would predict. This ranking directly expresses the fact that central Peninsular Spanish sibilant voicing is entirely contextdependent and non-contrastive. Since the devoicing and faithfulness constraints are completely subordinate to articulatory markedness, no distinctive sibilant voicing specifications are allowed, and neutral [S] adopts the least effortful laryngeal posture as a function of its position, subject, of course, to gradient variation. Since space limitations prevent a formal illustration of the relevant constraint evaluations here, we simply list the optimal lexical outputs by context: intervocalic VSV, postconsonantal CSV, word-initial SV, preconsonantal VSC, and word-final VS. Torreblanca's claim that sibilants may sponta- 
neously voice even before voiceless consonants, if empirically correct, suggests the maintenance of glottal vibration from the preceding vowel in VSC, similar to the explanation we proposed above for Ecuadorian prepausal contexts.

It is worthwhile to compare explicitly the postlexical evaluation of phrasal intervocalic sibilants in central Peninsular Spanish with those proposed above for medieval Spanish (Tableau 5), early modern Castilian (Tableau 7), and central highland Ecuadorian (Tableau 8). Assuming that * [ $\alpha$ voice] is dominant in the central Peninsular lexical phonology, neutral [S] is optimal in both wordfinal and word-initial positions. Given the pair of postlexical inputs VS|V and

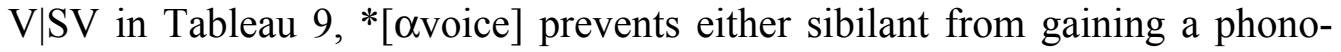
logical voicing specification in candidates (a) through (d). The only option is to merge the two inputs to VSV in (e), in which [S] is phonetically voiced via interpolation between vowels. As in medieval and highland Ecuadorian Spanish, word-final prevocalic sibilants surface as voiced in central Peninsular Spanish. However, only in the latter variety are word-initial postvocalic sibilants also voiced, as shown by [o zea] o sea "that is" in (9b). The combined effect of voicing in both contexts is that phrasal intervocalic sibilant contrasts are neutralized in favor of phonetically voiced [z], i.e., has ido and ha sido are realized as homophonous: [aziðo].

\begin{tabular}{|c|c|c|c|c|c|c|}
\hline $\mathrm{VS} \mid \mathrm{V}_{1}$ & $\mathrm{~V} \mid \mathrm{SV}_{2}$ & SPACE $_{\mathrm{SV}}$ & $*[\alpha$ voice $]$ & *MERGE & $\sigma\left[\begin{array}{ll}\mathrm{s} & 1 \\
\end{array}\right.$ & IDENTSIB(voice) \\
\hline a. $\mathrm{VzV}_{1}$ & $\mathrm{VsV}_{2}$ & 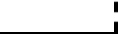 & $* ! *$ & & $* \quad$ & $* *$ \\
\hline b. $\mathrm{VsV}_{1}$ & $\mathrm{VzV}_{2}$ & 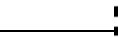 & $* ! *$ & & $*$ & $* *$ \\
\hline c. & $\mathrm{VsV}_{12}$ & 1 & $* !$ & $*$ & i & $* *$ \\
\hline d. & $\mathrm{VzV}_{12}$ & 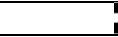 & $* !$ & $*$ & $*$ & $* *$ \\
\hline L $\mathrm{e}$. & $\mathrm{VSV}_{12}$ & 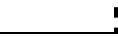 & & $*$ & & \\
\hline
\end{tabular}

Tableau 9: Phrasal intervocalic sibilants are [0voice]

(central Peninsular, postlexical ranking)

Several researchers have claimed that the appearance of syllable-initial voiced sibilants in modern Spanish dialects is actually a retention from medieval Spanish. For example, Toscano Mateus (1953) and Robinson (1979) argue that the Ecuadorian prevocalic voicing is archaic, a remnant of the medieval voicing. Based on the obvious parallel between word-final prevocalic voicing in highland Ecuador and the same voicing as hypothesized for medieval Spanish, it is tempting to view the former as a natural continuation of the latter. Given Kiparsky's claim that sound change enters the grammar postlexically, our analysis of sibilant devoicing suggests a different view. Specifically, the absence of a lexical sibilant voicing contrast in Ecuadorian Spanish implies that this variety must have gone through a prior stage of incipient, postlexical devoicing. As illustrated in Figure 4, Ecuadorian word-final prevocalic voicing is a more recent sound change, subsequent to Stage 2.2 of the medieval-tomodern Spanish chronology in Figure 3. As shown in Tableau 8, the postlexi- 
cal demotion of $\sigma_{[}[\mathrm{s}$ below *MERGE allows a surface contrast between phrases to emerge once again, but word-medial /s/ remains voiceless.

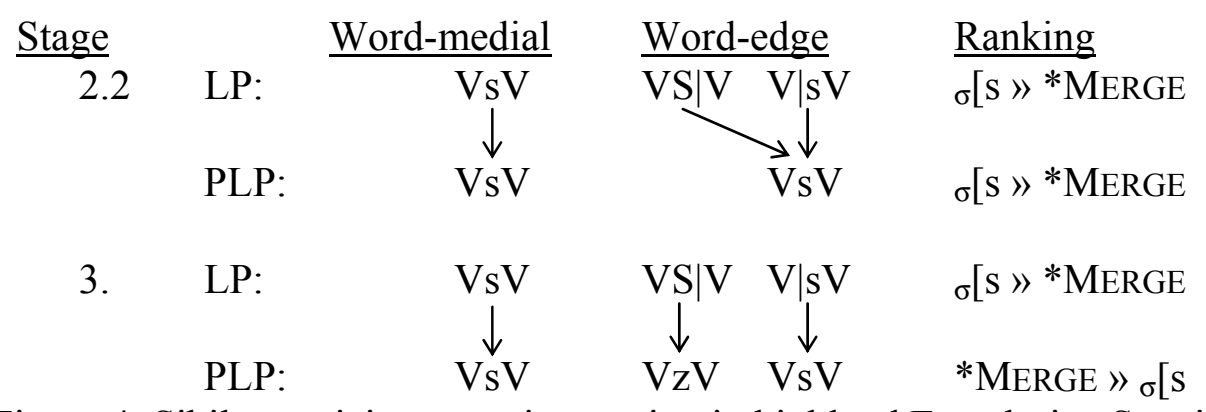

Figure 4: Sibilant voicing as an innovation in highland Ecuadorian Spanish

With regard to central Peninsular dialects, Espinosa (1935) claims that some speakers have maintained the medieval opposition between voiced and voiceless sibilants (for more recent evidence, see Salvador \& Ariza 1992). Based on the speech of his own informants, however, Torreblanca (1978, $1986 a, b)$ argues that the voicing of syllable-initial sibilants is driven by articulatory weakening, independently of the etymology of the word. Apparently, we are dealing with two distinct patterns here. For speakers who retain etymological sibilant voicing specifications, their situation approximates that of presentday Judeo-Spanish dialects in which the medieval voicing contrast is retained. These speakers have maintained the medieval ranking of *MERGE $» \sigma[\mathrm{s}$ in both the lexical and postlexical components. ${ }^{11}$ As for the true innovators, we follow Torreblanca (1986b): “[p]odríamos suponer que la sonorización moderna comenzó en estas provincias cuando todavía se conservaba la distinción fonológica medieval de sibilantes sordas y sonoras" (19). This suggests an alternative

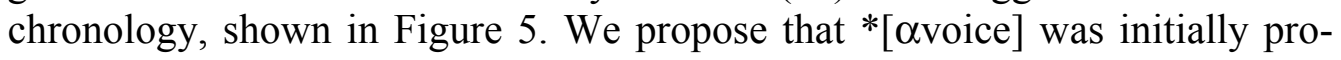
moted above *MERGE in the postlexical phonology (Stage 2.1) and that this reranking subsequently took place in the lexical phonology (Stage 2.2). The end result corresponds to the Peninsular dialects as described by Torreblanca, with phonetic voicing of syllable-initial sibilants. 


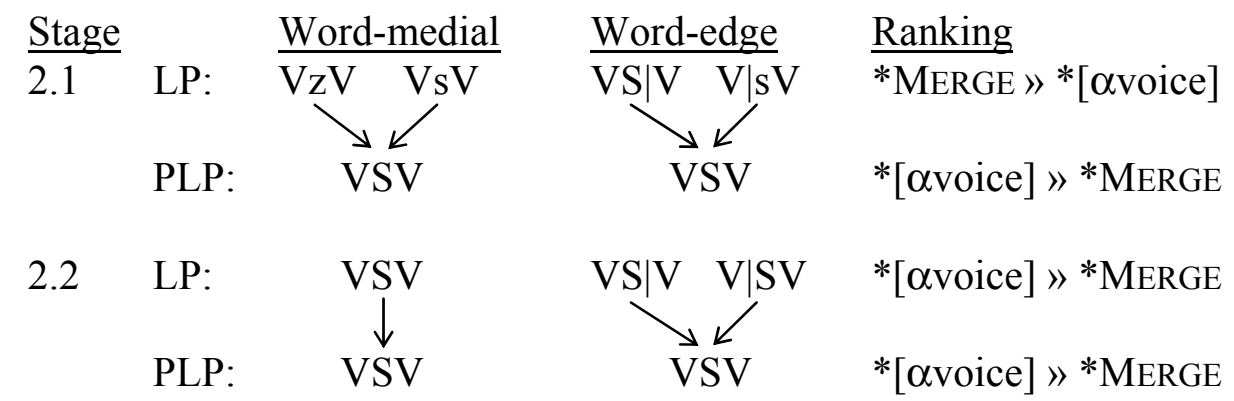

Figure 5: Sibilant voicing as an innovation in central Peninsular Spanish

\section{Theoretical implications and alternative accounts}

Both the medieval Castilian merger of voiced and voiceless sibilants and the voicing of prevocalic and prepausal $/ \mathrm{s} /$ in the Ecuadorian and central Peninsular dialects may be considered in some sense unusual and difficult to explain. Within the tradition of Romance philology, the devoicing of medieval Spanish sibilants is typically classified as a peculiar development, primarily because it sets Castilian Spanish apart from the other widely spoken Romance languages that have preserved sibilant voicing contrasts. As the medieval voiced sibilants occurred almost exclusively in intervocalic position, it has been argued that devoicing in such a highly sonorant environment contradicts the principles of articulatory economy, which otherwise seem to favor lenition of intervocalic consonants (Alarcos Llorach 1988). Also, devoicing had the effect of neutralizing contrasts in the syllable onset, a phonologically strong position in which contrasts are otherwise likely to be preserved (Widdison 1997).

In a functionalist, constraint-based framework such as DT, there is nothing unusual about sibilant voicing neutralization in the history of Spanish. The paradox of losing syllable-initial voiced sibilants in the highly sonorant intervocalic context is solved by the fact that voiced sibilants are themselves articulatorily and perceptually marked. In Section 3.3, we proposed a straightforward account of this change in terms of constraint re-ranking, whereby a positional markedness constraint requiring sibilants to be [-voice] in the syllable onset is promoted above *MERGE, resulting in the loss of voiced sibilants postlexically and then lexically. More generally, constraint-based theories such as OT and DT effectively resolve the apparent contradiction between universal phonetic tendencies and language-specific sound patterns. While functional constraints are universally available to any grammar, they are violable and can be ranked in different ways in different grammars.

Despite a vast philological literature on the devoicing of medieval Spanish sibilants, few generative phonologists have attempted a comprehensive analysis of the diachrony of Spanish sibilant voicing patterns. To our knowledge, 
only three generative studies make brief mention of plausible analyses of sibilant voicing neutralization (see Baker 2003, Harris 1969, and Martínez-Gil 1991), while Lipski (1989) constitutes the sole derivational account of wordfinal prevocalic sibilant voicing in central highland Ecuador. The representational assumption underlying all of these studies is that only two categories are relevant for sibilant voicing, namely [+voice] and [-voice]. In contrast, our account makes a crucial distinction between sibilants that are phonologically specified for [voice] and those that are phonetically targetless with respect to this feature, where sibilants of the latter category are subject to gradient and variable phonetic voicing through interpolation. This three-way distinction is motivated on a purely descriptive level by the fact that most descriptions of regressive voicing in contemporary Spanish highlight its style-dependent, gradient, and variable nature - all of which are hallmark characteristics of a phonetic process. ${ }^{12}$

On a theoretical level, the appeal to neutral [S] is attractive in that there is no need for an additional phonological constraint to account for the Spanish data (e.g., AGREE(voice); see Lombardi 1999, among others). Rather, gradient voicing assimilation follows "for free" as the result of phonetic interpolation between adjacent glottal targets. Furthermore, the voicing of sibilants before pauses in central Peninsular and highland Ecuadorian Spanish and before voiceless consonants in the former variety runs counter to the expectations of universal markedness, whereby phonologically voiceless obstruents are overwhelmingly preferred in these two syllable-final contexts in many languages. In contrast, the possibility of occasional spontaneous voicing in these positions is actually predicted by the analysis put forth here. In forms such as VS and VSC, phonetically targetless [S] may be voiced on some occasions due to the carryover of glottal adduction from the preceding vowel, regardless of what follows the sibilant.

A potential criticism of our analysis is that the possibility of neutral /S/ along with phonologically specified /s/ and /z/ introduces a universally noncontrastive phonetic category into the phonology. Such a move goes against the conventional Jakobsonian view of distinctive feature theory, in which the phonology can entertain only those phonetic distinctions that are contrastive in at least one of the world's languages. While a ternary underlying distinction in [voice] is clearly an anathema within the standard generative treatment of contrastiveness, no such problem arises under a systemic view of contrast. This is because DT regulates the well-formedness of contrasts directly via interacting constraints in the grammar. As we have seen, $\mathrm{SPACE}_{\mathrm{Sv}}$ ensures that an input distinction between $/ \mathrm{S} /$ and either $/ \mathrm{s} /$ or $/ \mathrm{z} /$ cannot survive in the output for perceptual reasons. As a result, it is possible to incorporate extra phonetic detail into the phonology without overpredicting the range of possible contrasts 
However, what rules out a theoretically possible grammar in which *MERGE dominates SPACE $_{S v}$, which would seem to overpredict a three-way surface contrast among the three sibilant categories? Ultimately, it will be necessary to decompose SPACE $_{S V}$ into a universal subhierarchy of constraints, each enforcing a different degree of perceptual distinctiveness as a function of the number of perceptual cues available across various phonetic contexts. The ranking of faithfulness relative to this hierarchy would account for typological patterns of sibilant voicing contrast. For example, compare medieval Spanish, which allowed contrast only intervocalically, with English, which contrasts [s] and [z] between vowels (pre[s]edent - pre[z]ident), word-initially ([s]ue $[\mathrm{z}] o o)$, and word-finally $(b u[\mathrm{~s}]-b u[\mathrm{z}])$. The fact that neutral $[\mathrm{S}]$ is universally non-contrastive implies that the most stringent $\mathrm{SPACE}_{\mathrm{SV}}$ constraint should be placed in GEN in OT, meaning that surface contrasts between [S] and either [s] or $[\mathrm{z}]$ can never be generated in any language.

Finally, how does the DT analysis compare to a more conventional OT approach that assumes neither the [0voice] category nor systemic constraints on contrast? The contrastiveness of sibilants in medieval Spanish might be accounted for by the ranking of faithfulness to underlying voicing values above a markedness constraint against voiced stridents. Sibilant devoicing would reflect the opposite ranking of these two constraints. However, evidence from phrasal sibilants in medieval and highland Ecuadorian Spanish shows that it is not only sufficient but necessary to combine the ternary voicing distinction with the systemic approach of DT. Consider an alternative analysis of the $h a[\mathrm{z}]$ ido versus ha [s]ido contrast, shown in Tableau 10. Here, we adopt the positional faithfulness constraint IDENT(voice/V_V), which preserves the obstruent voicing contrast between vowels, as well as the markedness constraint * [+strident, +voice]. If the neutral [S] category is unavailable to the phonology, then [s] is predicted both word-finally and word-initially in the lexical output. The approach fails postlexically, however, since the fully faithful candidate (a) is chosen incorrectly over (b).

\begin{tabular}{|c|c|c|c|c|c|}
\hline & & $\mathrm{Vs} \mid \mathrm{V}$ & $\mathrm{V} \mid \mathrm{sV}$ & IDENT(voice/V V) & $*[+$ strident,+ voice \\
\hline 承 & a. & $\overline{\mathrm{VsV}}$ & $\overline{\mathrm{Vs \textrm {V }}}$ & & \\
\hline & $\mathrm{b}$ & $\mathrm{VzV}$ & $\mathrm{VsV}$ & $* 1$ & * \\
\hline
\end{tabular}

Tableau 10: Standard input-output faithfulness fails postlexically

Neutralization avoidance is also necessary in addition to systemic markedness. Compare Tableau 8 above with Tableau 11, in which positional faithful-

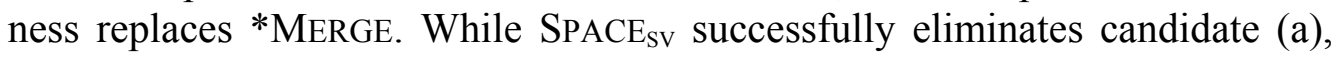
the remaining candidates all tie on input-output faithfulness, leaving $\sigma[\mathrm{s}$ to decide incorrectly in favor of (c). IDENT(voice/ $\mathrm{V}_{-} \mathrm{V}$ ) cannot distinguish among the mappings in (b), (c), and (d), but *MERGE in Tableau 8 does just that by favoring the non-neutralizing candidate $(\mathrm{d})$. Neutralization avoidance is suc- 
cessful in this case because of its asymmetrical relationship to non-systemic faithfulness. That is, a violation of *MERGE entails a violation of IDENT, but not vice-versa (see the discussion surrounding (12b)). The postlexical mapping of $\mathrm{VS} \mid \mathrm{V}$ to $\mathrm{VzV}$ in (d) violates input-output faithfulness, but since there is no input $\mathrm{V} \mid \mathrm{zV}$, due to the absence of word-initial / $\mathrm{z} /$ lexically, the mapping in (d) is non-neutralizing. ${ }^{13}$

\begin{tabular}{|rll||c|c|c|c|}
\hline & $\mathrm{VS} \mathrm{V}_{1}$ & $\mathrm{~V}_{\mathrm{s} \mathrm{V}_{2}}$ & SPACE $_{\mathrm{sV}}$ & IDENTSIB(voice/V_V) & $\sigma[\mathrm{s}$ & $*[\alpha$ voice $]$ \\
\hline \hline a. & $\mathrm{VSV}_{1}$ & $\mathrm{VsV}_{2}$ & $* !$ & & $*$ & $*$ \\
\hline b. & $\mathrm{VSV}_{12}$ & & & $*$ & $* !$ & \\
\hline c. & & $\mathrm{VsV}_{12}$ & & $*$ & & $*$ \\
\hline d. & $\mathrm{VzV}_{1}$ & $\mathrm{VsV}_{2}$ & & $*$ & $* !$ & $* *$ \\
\hline
\end{tabular}

Tableau 11: A DT approach without *MERGE fails postlexically

\section{Conclusion}

In this study, we have proposed an account of both the neutralization of sibilant voicing contrasts in the historical phonology of Spanish and the contextual patterning of sibilants at various diachronic stages. We have argued that a ternary distinction in obstruent [voice] provides a descriptively adequate distinction between phonological and phonetic sibilant voicing. In line with other recent applications of DT to both diachronic and synchronic phenomena, our analysis shows that a non-contrastive phonetic category can be incorporated into the phonology, so long as the well-formedness of surface contrasts is regulated directly by the grammar. From the constraint-based perspective of OT, there is nothing unusual about the Sisyphean fate of voiced sibilants throughout the history of Spanish. Constraints express observed universal phonetic tendencies, but languages can vary in the extent to which such tendencies are manifested because constraints are violable and subject to ranking permutation. Finally, we have demonstrated the formal utility of systemic contrast in accounting for sibilant voicing patterns in Spanish, and we encourage further exploration of this approach in other empirical domains.

\section{Notes}

* For discussion on many of the ideas presented in this paper, we wish to thank José Ignacio Hualde, John Lipski, Jaye Padgett, and Kimball Robinson. Thanks also to four anonymous reviewers whose comments and suggestions have proven extremely helpful. We alone are responsible for any remaining shortcomings.

${ }^{1}$ Robinson (1979) further argues that in the Cuenca sub-dialect of highland Ecuador, the /s/ of the prefix des- is voiced when the following stem begins with a vowel. When his informants first read the unfamiliar desalar "to remove salt" and desalar "to remove the wings" from a word list that he used to collect his data, they pronounced both items as [desalar]. After being made aware of the meanings of both words, they pronounced de-salar with a voiceless [s] and 
des-alar with [z]. When asked if there was any difference in the way that these two words are pronounced, they replied that des-alar contains a pause after the /s/ while de-salar does not. Robinson suggests that since no tokens of des-alar actually contained a pause, his informants most likely perceived prefix-final [z] as /s/ followed by a syllable boundary. In his later study, Lipski (1989:51) argues against "the conclusion that the Cuenca dialect systematically voices morpheme-final prevocalic /s/" and suggests instead that " $[\mathrm{t}]$ he most logical conclusion is lexicalization of a handful of items." In the present study, we treat only word-final prevocalic /s/voicing since both authors are in agreement on this point. Clearly, further empirical investigation is necessary to determine both the distribution and syllabification of $[\mathrm{z}]$ in highland Ecuadorian Spanish.

${ }^{2}$ Following Cohn (1990), Keating (1988, 1990), and others, Ernestus (2003) adopts the conventional view that the output of phonology serves as the input to the phonetic component. The phonological features [+voice] and [-voice] are then mapped to phonetic targets that are subsequently hooked up through interpolation. The analysis we propose involves systemic constraints that evaluate the perceptual distinctiveness of sibilant voicing in different contexts, including those that exhibit neutral [S]. Since these constraints are part of the phonological grammar, and since the gradient phonetic voicing of $[\mathrm{S}]$ must be present in the component where these constraints are operative, interpolation between targets cannot be relegated to lowlevel phonetic implementation. Instead, we adopt the position of Kirchner (1998) and Steriade (1997), among others, who eschew the derivational phonology-phonetics mapping in favor of a unified model that allows implementational factors to interact directly with the rest of the grammar.

${ }^{3}$ Note that candidate idealization in DT is a kind of tactical constraint on Richness of The Base and on GEN, the component of the OT model that maps inputs to outputs. If it turns out that other properties of a form (e.g., stress, vocalic distinctions, etc.) are relevant to a given analysis, then the idealization can easily be expanded to include them. While any generative phonological analysis necessarily abstracts away from irrelevant detail, DT simply makes the abstraction explicit in the form of idealized words. See Ní Chiosáin \& Padgett (2001) and Padgett (2003a,b,c) for further discussion.

${ }^{4}$ Thanks to Jaye Padgett (personal communication) for discussion on this point.

${ }^{5}$ In his analysis of Catalan rhotics, Padgett (2003c) proposes a similar positional augmentation constraint requiring a syllable-initial rhotic to be a strong trill. Both of these constraints might be reformulated in terms of SPACE constraints in DT, but we do not pursue this at present.

${ }^{6}$ An anonymous reviewer questions the inclusion of VSV as an input. If [S] is the neutralized version of $/ \mathrm{s} /$ or $/ \mathrm{z} /$ in coda position, preconsonantally or otherwise, how could we ever get a form in which it appears between vowels? Furthermore, given the surface contrast between intervocalic [s] and [z], Lexicon Optimization (Prince \& Smolensky 1993) predicts that learners would never posit underlying /S/ for either of the two surface forms because doing so would subsequently involve unfaithful input-output mappings. These observations are correct for medieval Spanish. However, Richness of The Base entails that VSV is a possible input universally, and factorial typology predicts that the ouput VSV should be possible under a dif-

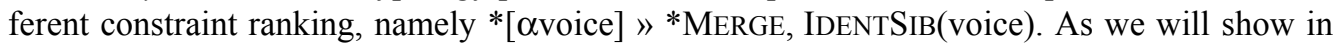
Section 4, such a ranking is consistent with the patterning of sibilants in central Peninsular Spanish.

${ }^{7}$ Recall that in medieval Spanish, /z/ never occurred word-initially, while only a limited number of learned words and borrowings from Arabic and Gallo-Romance began with either $/ \mathrm{d}^{\mathrm{z}} /$ or /3/ (Alarcos Llorach 1988, Penny 1993). Taking these few loanwords to be exceptions beyond 
the purview of the native grammar, we do not attempt to incorporate them in the present analysis.

${ }^{8}$ Recall from Section 2 that in medieval Spanish, apocope lead to the deaffrication of $/ \mathrm{t}^{\mathrm{s}} /$ and $/ \mathrm{d}^{\mathrm{z}} /$ word-finally, which was then extended to syllable-initial contexts (Harris-Northall 1992). As an anonymous reviewer points out, this change suggests a constraint banning affricates from coda position probably since the proto-language. Although we do not pursue it here, a plausible analysis might involve the interaction between a markedness constraint against affricates and the relevant faithfulness constraints, as well as SPACE constraints governing fricative-affricate contrasts across segmental contexts.

${ }^{9}$ Padgett (2003c) proposes a similar explanation in DT for the prohibition against word-final prevocalic trills in Catalan, e.g., $m a[r]$ està versus * $m a[\mathrm{r}]$ està "sea is". The tap is required in this position in order to maintain a sufficient contrast with word-initial intervocalic trills, e.g., $m a ̀$ [r] està "hand remained".

${ }^{10}$ An anonymous reviewer doubts that neutralization avoidance could be responsible for the word-final $/ \mathrm{S} / \rightarrow[\mathrm{z}]$ mapping in highland Ecuadorian Spanish in the same way that we have claimed for medieval Spanish. Because the Ecuadorian variety no longer has the lexical contrast between intervocalic $/ \mathrm{s} /$ and $/ \mathrm{z} /$ that medieval Spanish had, there would be no immediately obvious reason to avoid neutralization. However, such a criticism overlooks the fact that neutralization avoidance is operative in both the lexical and postlexical phonology, where the output of the former is the input to the latter (recall Section 3.2). In highland Ecuadorian Spanish, the lexical ranking of $\sigma[\mathrm{s} » *$ MERGE neutralizes the word-level contrast in favor of VsV (see Tableau 6). Postlexically, the re-ranking of these two constraints allows two underlyingly distinct phrases to remain distinct in the output by virtue of the voicing of word-final [S] between vowels.

${ }^{11}$ In a recent study of Istanbul Judeo-Spanish, Bradley \& Delforge (in press) present evidence that the lexical sibilant voicing contrast is maintained, whereas the voicing of word-final prevocalic sibilants is more variable than has been indicated in previous descriptions of JudeoSpanish. In terms of the present DT analysis, these results seem to suggest a lexical ranking of *MERGE ${ }^{\circ} \sigma$ s and a variable ranking of the two constraints postlexically, similar to Stage 2.1 of Figure 3.

${ }^{12}$ See Martínez-Gil (2003) and the references cited therein for several recent analyses in OT that treat gradient, partial voicing assimilation in Spanish obstruents as phonological. Interestingly, Martínez-Gil (2003:57) acknowledges that "[f]rom our present perspective, however, it appears that such attempts may have been premature or misconceived: I do not know of any compelling evidence suggesting that partial voicing assimilation is a phonological property, and not simply a fact of phonetic implementation. In fact, most available descriptions clearly indicate that the process is gradient, and thus typical of phonetic phenomena."

${ }^{13}$ This analysis works for Spanish but may turn out to be problematic for other languages that have word-initial voiced sibilants. Word-final prevocalic voicing would be neutralizing in this case, since the postlexical inputs $\mathrm{VS} \mid \mathrm{V}$ and $\mathrm{V} \mid \mathrm{zV}$ would both map to output $\mathrm{VzV}$.

\section{References}

Alarcos Llorach, Emilio. 1988. "De nuevo sobre los cambios fonéticos del siglo XVI". Actas del I Congreso Internacional de Historia de la Lengua Española ed. by M. Ariza, A. Salvador, \& A. Vindas, 47-59. Madrid: Arco/Libros. 
Alonso, Amado. 1967. De la pronunciación medieval a la moderna en español, vol. I. Madrid: Editorial Gredos.

--------- 1969. De la pronunciación medieval a la moderna en español, vol. II. Madrid: Editorial Gredos.

Alonso, Dámaso. 1962. "La fragmentación fonética peninsular". Enciclopedia Lingüística Hispánica, vol. I, Supplement, 85-103. Madrid: Consejo Superior de Investigaciones Científicas.

Baker, Gary. 2003. "Sibilant Dissimilation and Dispersion in the History of Spanish". Ms., University of Florida, Gainesville.

Beckman, Jill. 1997. "Positional Faithfulness, Positional Neutralization, and Shona Vowel Harmony". Phonology 14:1.1-46.

--------. 1998. Positional Faithfulness. Ph.D. dissertation, University of Massachusetts, Amherst.

Bradley, Travis G., \& Ann Marie Delforge. In press. "Phonological Retention and Innovation in the Judeo-Spanish of Istanbul". To appear in the Selected Proceedings of the $8^{\text {th }}$ Hispanic Linguistics Symposium. Somerville, MA: Cascadilla Proceedings Project.

Catalán, Diego. 1957. "The End of the Phoneme /z/ in Spanish”. Word 13.283322.

Chen, Matthew. 1970. "Vowel Length Variation as a Function of the Voicing of Consonant Environment". Phonetica 22.129-159.

Cohn, Abigail. 1990. Phonetic and Phonological Rules of Nasalization. Ph.D. dissertation, University of California, Los Angeles.

Cole, Ronald. A., \& William E. Cooper. 1975. "Perception of Voicing in English Affricates and Fricatives". Journal of the Acoustical Society of America 58.1280-1287.

Denes, Peter. 1955. "Effect of Duration on the Perception of Voicing". Journal of the Acoustical Society of America 27.761-764.

Ernestus, Mirjam. 2003. "The Role of Phonology and Phonetics in Dutch Voice Assimilation". The Phonological Spectrum, Volume I: Segmental structure ed. by Jeroen van de Weijer, Vincent J. van Heuven, \& Harry van der Hulst, 119-144. Amsterdam: John Benjamins.

Espinosa, Aurelio M. 1935. Arcaísmos dialectales: la conservación de s y z sonoras en Cáceres y Salamanca. Madrid: Anejo XIX de la Revista de Filología Española.

Flemming, Edward. 1995. Auditory Representations in Phonology. Ph.D. dissertation, University of California, Los Angeles.

-------. 2002. Auditory Representations in Phonology. New York: Routledge.

Ford, J. D. M. 1900. “The Old Spanish Sibilants". Havard Studies and Notes in Philology and Literature 7.1-182.

Galmés de Fuentes, Álvaro. 1962. Las sibilantes en la Romania. Madrid: Gredos. 
Haggard, Mark. 1978. "The Devoicing of Voiced Fricatives". Journal of Phonetics 6.95-102.

Harris, James. 1969. Spanish Phonology. Cambridge, Mass.: MIT Press.

-------. 1983. Syllable Structure and Stress in Spanish. Cambridge, Mass.: MIT Press.

Harris-Northall, Ray. 1992. "Devoicing, Affrication and Word-Final $-z$ in Medieval Spanish". Hispanic Linguistics 4.245-274.

Holt, D. Eric. 2003. "The Emergence of Palatal Sonorants and Alternating Diphthongs in Hispano-Romance". Optimality Theory and Language Change (= Studies in Natural Language and Linguistic Theory 56) ed. by D. Eric Holt, 285-305. Dordrecht: Kluwer Academic Publishers.

Hooper, Joan B. 1972. "The Syllable in Phonological Theory". Language 48.525-540.

Itô, Junko, \& Armin Mester. 2001. "Structure Preservation and Stratal Opacity in German". Segmental Phonology in Optimality Theory: Constraints and representations ed. by Linda Lombardi, 261-295. Cambridge: Cambridge University Press.

--------. In press. "Systemic Markedness and Faithfulness". Proceedings of Chicago Linguistics Society 39.

Jongman, Allard. 1989. "Duration of Fricative Noise Required for Identification of English Fricatives". Journal of the Acoustical Society of America 85.1718-1725.

Joos, Martin. 1952. “The Medieval Sibilants”. Language 28.222-231.

Jungeman, Fredrick, H. 1955. La teoría del sustrato y los dialectos hispanoromances y gascones. Madrid: Gredos.

Keating, Patricia. 1988. "Underspecification in Phonetics". Phonology 5.275292.

-----. 1990. "The Window Model of Coarticulation: Articulatory evidence". Papers in Laboratory Phonology 1: Between the grammar and physics of speech ed. by J. Kingston \& M. Beckman, 451-470. Cambridge: Cambridge University Press.

Kiddle, Lawrence B. 1977. "Sibilant Turmoil in Middle Spanish". Hispanic Review 45.327-336.

Kiparsky, Paul. 1985. "Some Consequences of Lexical Phonology". Phonology Yearbook 2:85-138.

----.. 1995. "The Phonological Basis of Sound Change". The Handbook of Phonological Theory ed. by John A. Goldsmith, 640-670. Cambridge, Mass.: Blackwell.

------. 1998. "Paradigm Effects and Opacity". Ms., Stanford University.

Kirchner, Robert. 1998. An Effort-based Approach to Consonant Lenition. Ph.D. dissertation, University of California, Los Angeles. 
Lantolf, James P. 1974. Linguistic Changes as a Socio-cultural Phenomenon: A study of the Old Spanish sibilant devoicing. Ph.D. dissertation, Pennsylvania State University.

--------. 1979. "Explaining Linguistic Change: The loss of voicing in the Old Spanish sibilants". Orbis 28.290-315.

Liberman, Mark, \& Janet Pierrehumbert. 1984. "Intonational Invariance under Changes in Pitch Range and Length". Language Sound Structure ed. by M. Aronoff \& R. T. Oehrle, 157-233. Cambridge, Mass.: MIT Press.

Lindblom, Björn. 1986. "Phonetic Universals in Vowel Systems". Experimental Phonology ed. by J. J. Ohala \& J. J. Jaeger, 13-44. Orlando: Academic Press.

---------. 1990. "Explaining Phonetic Variation: A sketch of the H\&H theory". Speech Production and Speech Modeling, ed. by W. J. Hardcastle \& A. Marchal, 403-439. Dordrecht: Kluwer Academic Publishers.

Lipski, John. 1989. “/s/-Voicing in Ecuadoran Spanish: Patterns and principles of consonantal modification". Lingua 79.49-71.

Lloyd, Paul M. 1987. From Latin to Spanish. Philadelphia: American Philosophical Society.

Lombardi, Linda. 1999. "Positional Faithfulness and Voicing Assimilation in Optimality Theory". Natural Language and Linguistic Theory 12.267-302.

Malkiel, Yakov. 1971. "Derivational Transparency as an Occasional CoDeterminant of Sound Change: A New Causal Ingredient in the Distribution of '-ç-' \& '-z-' in Ancient Hispano-Romance". Romance Philology 25.1:1-52.

Martinet, André. 1952. "Function, Structure, and Sound Change". Word 8:1.132.

-------. 1955. Économie des changements phonétiques. Bern: A. Francke.

1964. Elements of General Linguistics. Chicago: University of Chicago Press.

Martínez-Gil, Fernando. 1991. "The Insert/Delete Parameter, Redundancy Rules, and Neutralization Processes in Spanish". Current Studies in Spanish Linguistics ed. by Héctor Campos \& Fernando Martínez-Gil, 495-571. Washington, D.C.: Georgetown University Press.

--------. 2003. "Resolving Rule-Ordering Paradoxes of Serial Derivations: An Optimality Theoretical account of the interaction of spirantization and voicing assimilation in Peninsular Spanish”. Theory, Practice, and Acquisition ed. by Paula Kempchinsky \& Carlos-Eduardo Piñeros, 40-67. Somerville, Mass.: Cascadilla Press.

Massaro, Dominic. W., \& Michael. M. Cohen. 1977. "Voice Onset Time and Fundamental Frequency as Cues to the /zi/ - /si/ Distinction". Perception and Psychophysics 22:4.373-382. 
McCarthy, John J., \& Alan Prince. 1993. "Prosodic Morphology I: Constraint Interaction and Satisfaction". Ms., University of Massachusetts, Amherst, \& Rutgers University, New Brunswick, NJ.

---------. 1995. "Faithfulness and Reduplicative Identity". University of Massachusetts Occasional Papers in Linguistics 18 ed. by J. Beckman, S. Urbanczyk \& L. Walsh, 249-384. Amherst, Mass.: Graduate Linguistic Student Association.

Montoliu, Manuel. 1945. "La lengua española en el siglo XVI". Revista de Filología Española 29.153-160.

Navarro Tomás, Tomás. 1977. Manual de pronunciación española $\left(19^{\text {th }} \mathrm{ed}\right.$.). Madrid: Consejo Superior de Investigaciones Científicas.

Ní Chiosáin, Máire, \& Jaye Padgett. 2001. "Markedness, Segment Realization, and Locality in Spreading”. Segmental Phonology in Optimality Theory: Constraints and Representations ed. by Linda Lombardi., 118-156. Cambridge: Cambridge University Press.

Padgett, Jaye. 2003a. "Contrast and Post-Velar Fronting in Russian". Natural Language and Linguistic Theory 21.39-87.

--------. 2003b. "The Emergence of Contrastive Palatalization in Russian". Optimality Theory and Language Change ed. by D. Eric Holt, 307-335. Dordrecht: Kluwer Academic Publishers.

--------. 2003c. "Systemic Contrast and Catalan Rhotics". Ms., University of California, Santa Cruz.

Padgett, Jaye, \& Marzena Zygis. 2003. "The Evolution of Sibilants in Polish and Russian". Ms., University of California, Santa Cruz, \& Zentrum für Allgemeine Sprachwissenschaft, Berlin.

Penny, Ralph. 1993. "Neutralization of Voice in Spanish and the Outcome of the Old Spanish Sibilants: A case of phonological change rooted in morphology". Hispanic Linguistic Studies in Honour of F. W. Hodcroft ed. by David Mackenzie \& Ian Michael, 75-88. Oxford: Dolphin.

---------. 2002. A History of the Spanish Language. Cambridge: Cambridge University Press.

Pensado, Carmen. 1993. "El ensordecimiento castellano: ¿un «fenómeno extraordinario»?" Anuario de lingüística hispánica 9.195-230.

Prince, Alan, \& Paul Smolensky. 1993. "Optimality Theory: Constraint interaction in generative grammar". Ms., Rutgers University, New Brunswick, \& University of Colorado, Boulder.

Robinson, Kimball. 1979. "On the Voicing of Intervocalic $s$ in the Ecuadorian Highlands". Romance Philology 33.137-143.

Salvador Plans, Antonio, \& Manuel Ariza. 1992. "Sobre la conservación de sonoras en la provincia de Cáceres". Zeitschrift für romanische Philologie 108.276-292. 
Sanders, Nathan. 2002. "Dispersion in OT: Middle Polish nasal vowels". WCCFL 21 Proceedings ed. by Line Mikkelsen \& Christopher Potts, 415428. Somerville, Mass.: Cascadilla Press.

-------. 2003. Opacity and Sound Change in the Polish Lexicon. Ph.D. dissertation, University of California, Santa Cruz.

Smith, Caroline L. 1997. "The Devoicing of /z/ in American English: Effects of local and prosodic context". Journal of Phonetics 25.471-500.

Smith, Jennifer. 2002. Phonological Augmentation in Prominent Positions. Ph.D. dissertation, University of Massachusetts, Amherst.

Steriade, Donca. 1997. "Phonetics in Phonology: The case of laryngeal neutralization". Ms., University of California, Los Angeles.

Stevens, Kenneth N., Sheila E. Blumstein, Laura Glicksman, Martha Burton, \& Kathleen Kurowski. 1992. "Acoustic and Perceptual Characteristics of Voicing in Fricatives and Fricative Clusters". Journal of the Acoustical Society of America 91:2979-3000.

Torreblanca, Máximo. 1978. "El fonema /s/ en la lengua española". Hispania 61.498-503.

-------. 1986a. "La 's' sonora prevocálica en el español moderno". Thesaurus 41.59-69.

-------. 1986b. "La sonorización de /s/ y /9/ en el noroeste toledano". Lingüistica Española Actual 8:1.5-19.

Toscano Mateus, Humberto. 1953. El español del Ecuador. Madrid: Consejo Superior de Investigación Científica.

Westbury, J., \& Patricia Keating. 1986. "On the Naturalness of Stop Consonant Voicing". Journal of Linguistics 22.145-166.

Widdison, Kirk A. 1995. "In Defense of A. Alonso's Views on Old Spanish Sibilant Unvoicing”. Romance Philology 49.25-33. 1996. "Physical Constraints on Sibilant-voicing Patterns in Spanish Phonology". Proceedings of the 1995 Desert language and Linguistics Symposium ed. by J. Turley, 37-42. Provo, Utah: BYU Linguistics Department.

-------. 1997. "Phonetic Explanations for Sibilant Patterns in Spanish". Lingua 102.253-264. 